\title{
RESEARCH OF THE DOMESTIC MARKET OF MEDICATIONS FOR COUGH TREATMENT
}

\author{
๑o. I. Onyshkiv, I. P. Lech, T. A. Hroshovyi \\ Ternopil State Medical University by I.Ya. Horbachevsky
}

\begin{abstract}
Summary: the domestic pharmaceutical market of medication for cough treatment has been analyzed. The medication was structured due to the ATC-classification, manufacturing countries and range of medicines in the nomenclature were established. It was found that $51,55 \%$ of medications for cough treatment are foreign-made, Ukrainian medicines are $48,45 \%$. Syrups $(31,67 \%)$ are the most common form of medication release in this group, pills and combination herbal medicinal products amount to $15,53 \%$ and $10,59 \%$ respectively. The results can be used in the practice of pharmaceutical companies in order to develop the optimal range.

Key words: medications for cough treatment, pharmaceutical market.
\end{abstract}

Introduction. Respiratory diseases are among the most common human diseases and according to the structure of general morbidity, they take the leading positions by the number of days of incapacity for work, causes of disability and have the fifth place in the range of the mortality reason. For the last five years the prevalence of respiratory diseases among the population of Ukraine has increased by $10,38 \%$. That is coursed by the conditions at work, so occupational diseases appear, unfavorable ecological situation in the country and development of smoking among the population - one of the most unfavorable common bad habits [1].

Coughing, especially for a long time and hard, is the most common cause of a patient's appointment to the doctor. Usually, acute cough, often accompanied by upper respiratory tract infection, stops independently and rarely require hospitalization. Chronic cough is often a symptom of many serious chronic respiratory diseases, and may be the only sign of various extrapulmonary disease, including diseases of the upper respiratory tract or gastrointestinal tract $[2,3]$.

Nowadays, the pharmaceutical market has more and more new medications (M) of different manufacturers for cough treatment, so the quality of medical care depends on the reliability and availability of pharmaceutical information. Therefore, preparing of the market research concerning the medications used for treatment of bronchopulmonary segment has a big importance.

The aim is to study the range of medications for cough treatment, available on the pharmaceutical market of Ukraine, to determine the feasibility of developing new antitussive medications and opportunities to take them particular market place.

Methods of the research. The market analysis of medications was passed in accordance with various parameters, including the countries of the manufacturers, dosage forms and content of active pharmaceutical ingredients of medications for cough treatment and its origin. Statistical analysis of the data was prepared using Microsoft Excel 8.

Results and discussion. We followed the ATCclassification system in marketing study of the domestic market of medications for cough treatment. According to this classification the researched medications belong to the group R05 «Remedies, used in cough and catarrhal diseases». The range of medications of four subgroups was studied, namely R05C «Expectorants, except combined drugs containing antitussive medications», R05D "Antitussive medications, except combined drugs containing expectorants», R05F «Combined drugs, which contain antitussive medications and expectorant» and R05X «Other combined drugs that are used in cough and catarrhal diseases» [4].

The analysis of the State Register of medications, approved for medical use in Ukraine, showed that the range of complete medications for cough treatment as of January 2015, has 161 names, of which more than half $-73,4 \%$ are expectorants, including expectorants which stimulate the secretion of bronchial glands - 36,7 \% expectorants mucolytic - 36,7 \%, antitussive drugs - 10,5\%, including antitussive drugs with central and peripheral effects $-3,1 \%$, combined antitussive drugs $-7,5 \%$. Other $16,1 \%$ are combined drugs of expectorants and antitussive drugs [5].

In accordance with the results of studies, it was found that the market in Ukraine of medications for cough treatment is presented mainly by foreignmade medications - 51,55 \%, domestic medications have only $48,45 \%$ of the studied range at the classified group. The study of import countries for cough treatment showed that deliveries to Ukraine

ISSN 2312-0967. Pharmaceutical review. 2015. № 1 
of this group are provided from 17 countries of the world (Fig. 1).

The largest number of supposed medications for cough treatment is manufactured in India and Germany, representing at the domestic pharmaceutical market respectively $33,73 \%$ and $26,51 \%$ of the range. Active positions among importing countries are occupied by Czech Republic and Turkey $-4,82 \%$ each in the range. The share of medications of other countries represented at the domestic market is small and takes $1-4 \%$.

Concerning domestic manufacturers, we can say that the range of Ukrainian antitussive medications consists of 78 items, so, the number of medications that are produced within a country, Ukraine takes the first place. Three leaders also include: India, representing 28 medications on the market and Germany - 22 medications. Manufacture of domestic medications for cough treatment are represented by 27 manufacturers. The leader position by quantity of product range which are produced and represented at the domestic market takes JSC «Liktravy» (12 items), second place is taken by LLC «FF «Zdorovia» (11 medications of the general range at the domestic manufacture), third place - FF JSC «Viola», which produces 10 medications for cough treatment. Production capacity of the domestic pharmaceutical enterprises can satisfy the needs of the population by relatively cheap medications for cough treatment.

The modern pharmaceutical market in Ukraine has a wide range of medication for cough treatment. The comparative evaluation of the range of $\mathrm{R} 05$ group, represented in the pharmaceutical market of Ukraine regarding dosage form indicates that this group is represented with variety of dosage forms. The largest share among them is syrups, tablets and combination herbal medicinal products. Other medication forms amount to about $42,21 \%$ of the range at the group in Ukraine (Fig. 2).

Also it should be emphasize that the manufacture of medications for cough treatment is carried out mainly by modifying drugs of traditional nomenclature, such as Ambroxol, Bromhexine, Acetylcysteine and manufacture of generic products, which determines the existence of such a wide range of antitussive medications due to the dosage form. However, comparing the ratio of registered antitussive medications with the previous years, it should be mentioned that the number at the period from 2009 to 2015 decreased by approximately $67 \%[5,6]$. Perhaps, the reason is difficulties of reregistration, especially the higher price of this process.

After analyzing medications for cough treatment, presented in the pharmaceutical market of Ukraine,

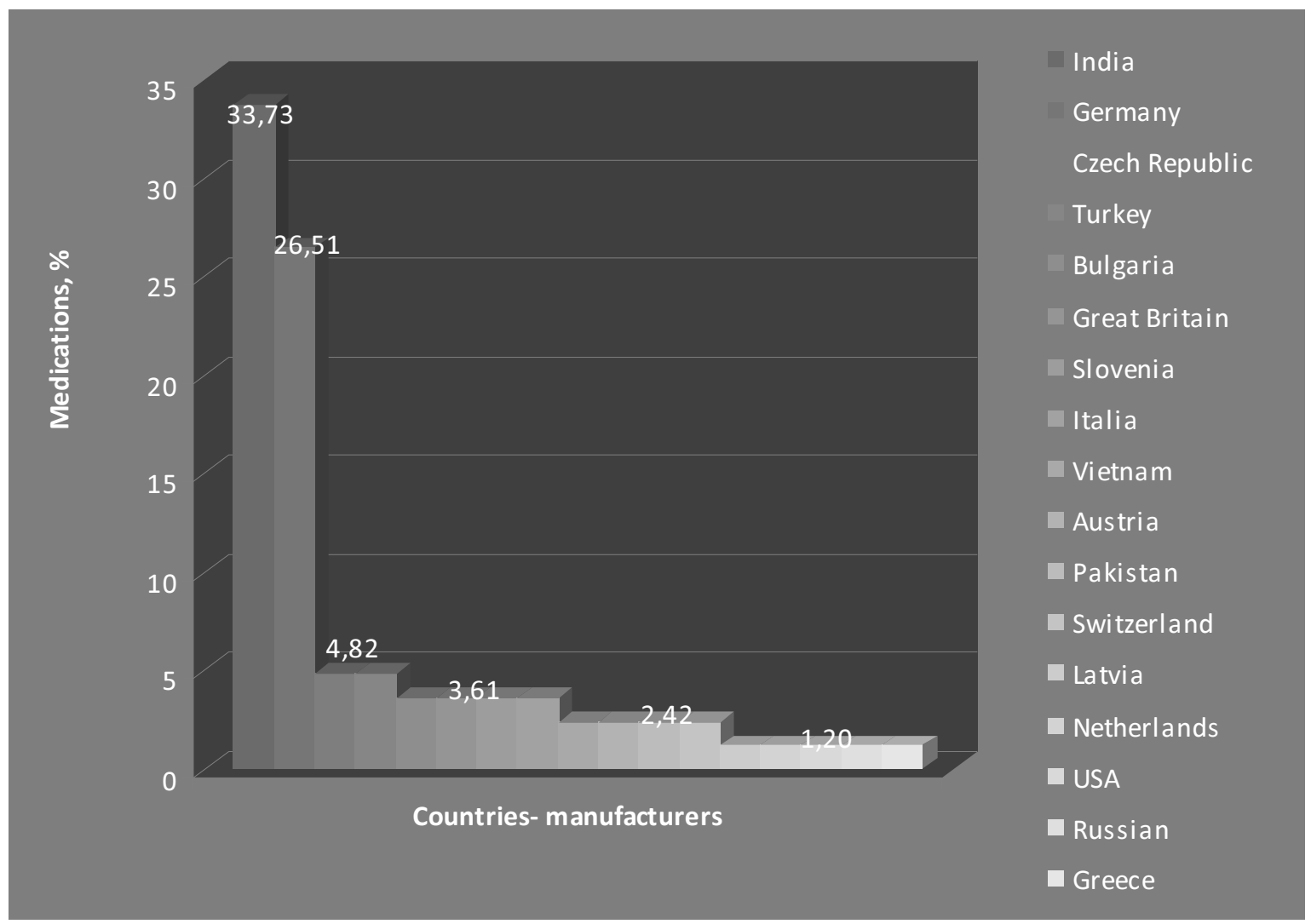

Fig. 1. Distribution of medication range for cough treatment due to the manufacturing countries

ISSN 2312-0967. Фармацевтичний часопис. 2015. № 1 


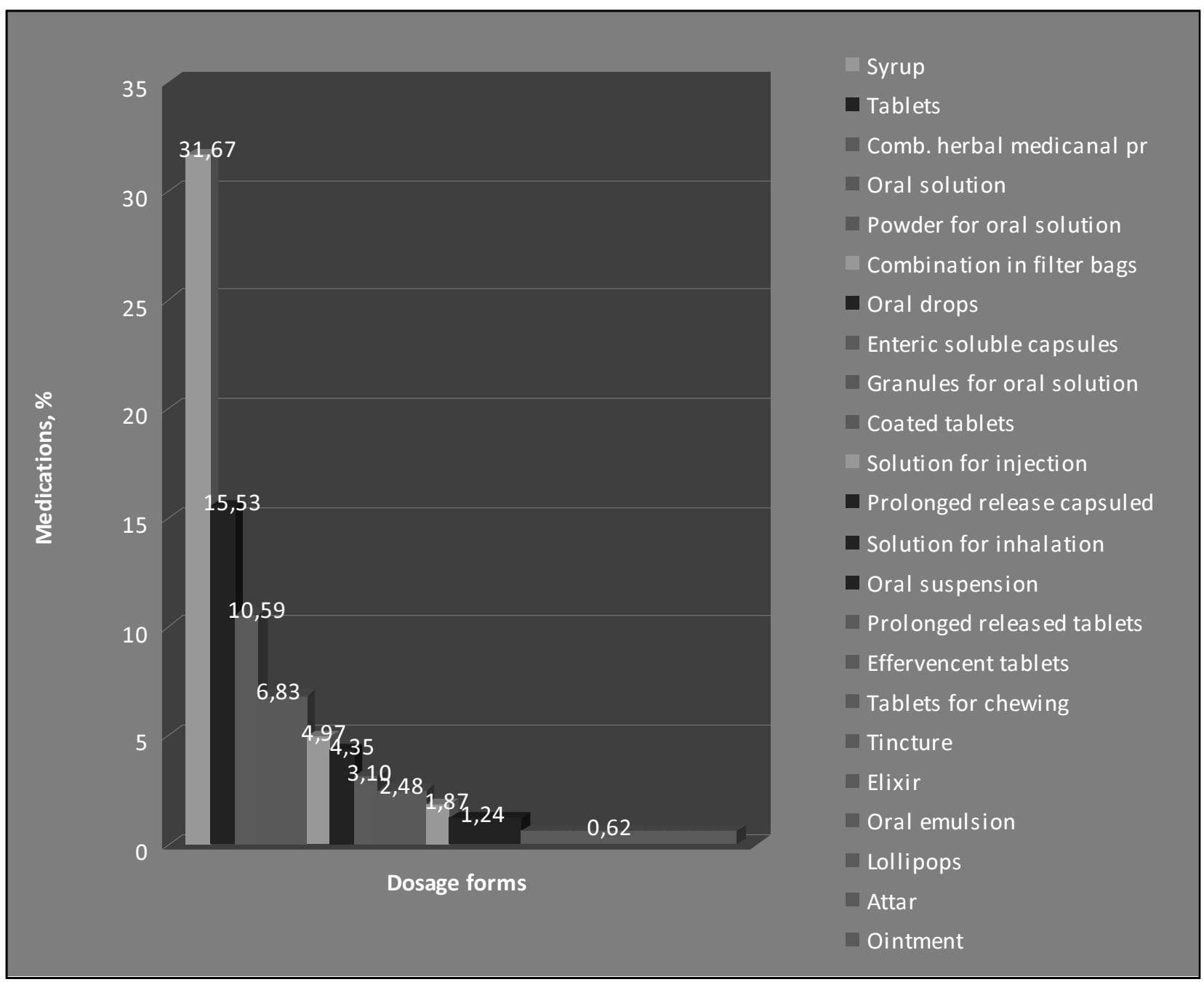

Fig. 2. Distribution of medications for cough treatment due to their dosage forms

due to the number of active pharmaceutical ingredients, it was found that the largest share (59\%) has one-component products (Fig. 3). It should be mentioned that the vast majority of oneand two-component medications for cough treatment are drugs that contain synthetic components. Three- or more component medications usually are of herbal origin or a combination of chemical and natural active pharmaceutical ingredients.

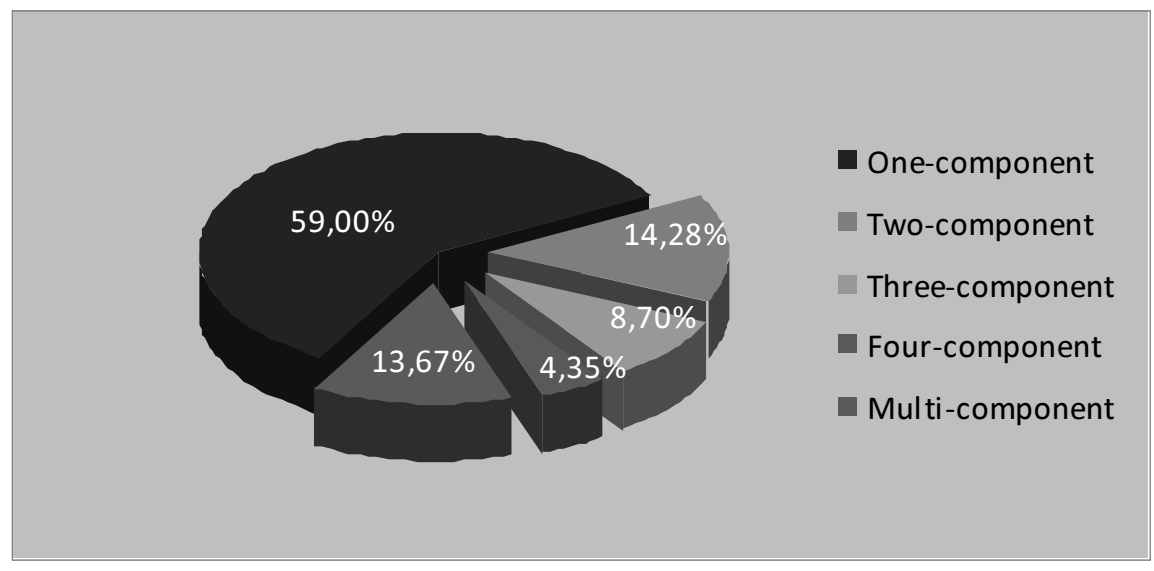

Fig. 3. Distribution of medication range for cough treatment due to the number of active pharmaceutical ingredients

ISSN 2312-0967. Pharmaceutical review. 2015. № 1 
Concerning the manufacturing, we can make the conclusion that domestic manufacturers produce oneor two-component medications, while foreign companies are focused on producing three- or more component medications for cough treatment. Taking into consideration the fact that an integrated approach should be used for the treatment of diseases of the bronchopulmonary segment, antitussive medications have to provide effects on different parts of the pathological process. That's why the development of multi-component group of medications is necessary to provide citizens with high-quality health care.

Analyzing the data shown in Fig. 4, we specify that manufacturers mostly offer medications of natural origin $(49,68 \%)$. generic or traditional medications with strong demand at this market segment.

Conclusions. 1. The research on the medication range for cough treatment registered in the pharmaceutical market of Ukraine was realized. As a result of studies, it was found that the Ukrainian market of medications for cough treatment is based mostly on foreign manufacturers. The analysis of the structure of foreign medication manufacturers at the domestic market showed that the leader by the number of offered drugs are India and Germany, representing at the domestic pharmaceutical market respectively $33,73 \%$ and $26,51 \%$.

2. It was examined that pharmaceutical manufacturers in Ukraine supply $48,45 \%$ of their

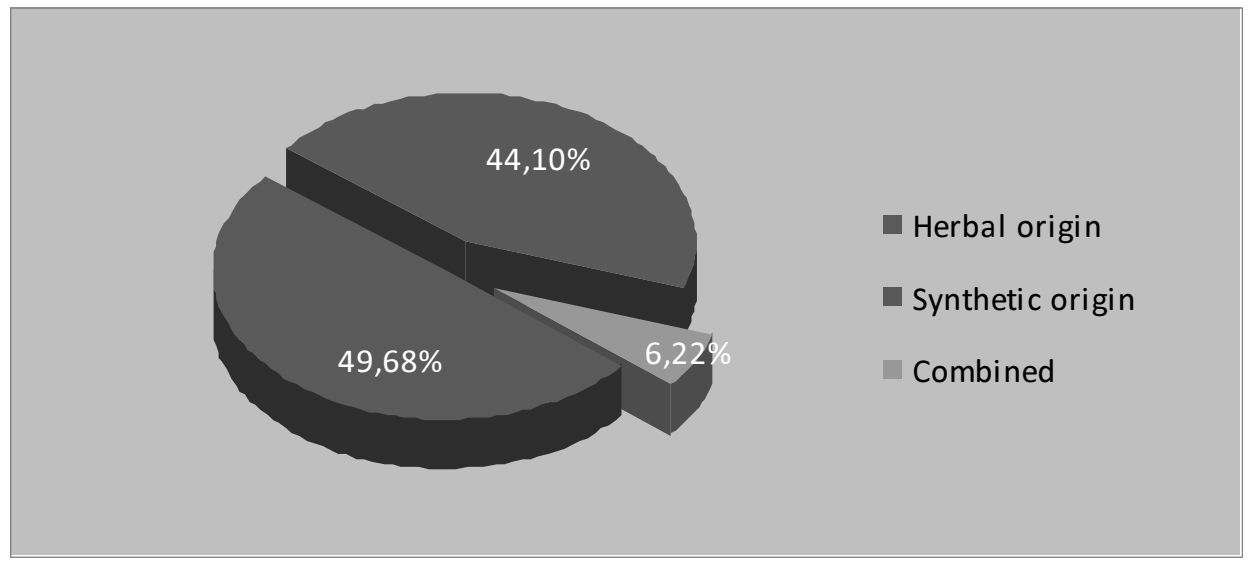

Fig. 4. Distribution of medication range for cough treatment due to the origin of active pharmaceutical ingredients

The analysis of herbal medications for cough treatment due to the added type of medicine raw material, showed that among the most used herbs for antitussive and expectorant medications are: Marshmallow (14 M), Licorice (11), Creeping thyme (9) Waybread (8), Hedera helix (7) and Coltsfoot (5). Generally, the list of medicinal plants includes 80 items. Of course, herbal medications have strong demand nowadays and in the future too. However, there is a possibility of reducing the share of herbal medications at the domestic market due to the competitive environment. First of all, as a result of lack of sufficient marketing support and updating the nomenclature of medications.

Marketing analysis of the structure of synthetic drugs in accordance with a separate active substance (international non-proprietary name) shows the maximum share of the investigated group range based on Ambroxol - 27 trade names (16,77 \%), Acetylcysteine - 15 trade names (9,32 \%), Bromhexine -7 trade names (4,35 \%). In our opinion, attention should be paid to the manufacturing of new competitive domestic synthetic original medications for cough treatment, because nowadays, a manufacturer in Ukraine is only focused on the medication range for the cough treatment to the market 27 enterprises manufacture them. CJSC «Liktravy», LLC «FF «Zdorovia», JSC FF «Viola» take leading positions.

3. The analysis of the range at the investigated group of dosage forms has showed that their main share $(31,67 \%)$ is presented in the form of syrups, $15,53 \%$ of medications are pills, $10,59 \%$ of medications are in the form of medicinal herbs.

4. After analyzing medications for cough treatment presented at the pharmaceutical market of Ukraine, due to number of active pharmaceutical ingredients, it was found that one-component medications have $59 \%$ of the studied range, so the development of multi-component drugs is necessary to provide the population with qualitative health care.

5. According to the market analysis, it was examined that among medications for cough treatment the share of natural origin drugs is 46,68 \%. The most used herbs are: Marshmallow, Licorice and Creeping Thyme.

6 . The obtained results indicate the need to update the range of domestic medications for cough treatment. After all, domestic manufacture is mainly based on the modification of the traditional medication nomenclature and generic drugs manufacturing.

ISSN 2312-0967. Фармацевтичний часопис. 2015. № 1 
Фармацевтичний менеджмент, маркетинг та логістика

Pharmaceutical management, marketing and logistics

\section{References}

1. Medical and demographic situation and organization of health care in 2010: results of health care system activity and realization of the economic reform program in 2010 2014 «Prosperous Society, Competitive Economy, Effective Country». - K.: Ministry of Health of Ukraine, 2011. - 104 p.

2. Buniatian N. D. Diagnosis and cough treatment in the practice of physician / N. D. Buniatian, D. B. Utyshev, A. V. Svyrydenko // Russ. Med. Jour. - 2010. - No.18 (18). - P. 1145-1148.

3. Shvaiko L. I. Cough as a symptom of various diseases /
L. I. Shvaiko // Medical newspaper «Health of Ukraine». 2008. - No. 3 (1). - P. 45-47.

4. Compendium. [electronic source]. - access mode: http:/ /compendium.com.ua/

5. Registry of Medicines [electronic source]. - access mode: http://mozdocs.kiev.ua

6. Basakina I. I., Dmytrievskyi D. I., Analytical review of the domestic market of medications for cough treatment / I. I. Basakina, D. I. Dmytrievskyi // Ukrainian Journal of Clinical and Laboratory Medicine. - 2009. - No. 3 (4). P. 15-19.

\title{
ДОСЛІДЖЕННЯ ВІТЧИЗНЯНОГО РИНКУ ЛІКАРСЬКИХ ЗАСОБІВ ДЛЯ ЛІКУВАННЯ КАШЛЮ
}

\author{
О. І. Онишків, І. П. Лех, Т. А. Грошовий \\ Тернопільський державний медичний університет імені І. Я. Горбачевського
}

Резюме: проаналізовано вітчизняний фармацевтичний ринок засобів для лікування кашлю. Здійснено структуризацію цих препаратів за АТС-класифікацією, встановлено країни та фірми-виробники, асортимент лікарських засобів у номенклатурі. Виявили, що лікарські засоби для лікування кашлю на 51,55 \% представлені ліками закордонного виробництва, українські препарати становлять 48,45 \%. Найпоширеніша форма випуску ліків цієї групи - сиропи (31,67 \%), на таблетки та лікарські збори припадає 15,53 \% та 10,59 \% відповідно. Отримані результати можуть бути використані у практичній діяльності фармацевтичних підприємств 3 метою формування оптимального асортименту.

Ключові слова: лікарські засоби для лікування кашлю, фармацевтичний ринок.

\section{ИССЛЕДОВАНИЕ ОТЕЧЕСТВЕННОГО РЫНКА ЛЕКАРСТВЕННЫХ СРЕДСТВ ДЛЯ ЛЕЧЕНИЯ КАШЛЯ}

\section{О. И. Онышкив, И. П. Лех, Т. А. Грошовый \\ Тернопольский государственный медицинский университет имени И. Я. Горбачевского}

Резюме: проанализирован отечественный фармацевтический рынок лекарственных средств для лечения кашля. Произведена структуризация данных препаратов по АТС-классификации, установлены страны и фирмыпроизводители, ассортимент лекарственных средств в номенклатуре. Обнаружили, что лекарственные средства для лечения кашля на 51,55 \% представлены лекарствами зарубежного производства, украинские препараты составляют 48,45 \%. Самая распространенная форма выпуска лекарств этой группы - сиропы (31,67 \%), на таблетки и лекарственные сборы приходится 15,53 \% и 10,59 \% соответственно. Полученные результаты могут быть использованы в практической деятельности фармацевтических предприятий с целью формирования оптимального ассортимента .

Ключевые слова: лекарственные средства для лечения кашля, фармацевтический рынок.

Отримано 16.03.2015

ISSN 2312-0967. Pharmaceutical review. 2015. № 1 